\title{
Interventions in the Alteration on Lingual Frenum: Systematic Review
}

\author{
Priscilla Poliseni Miranda ${ }^{1}$ Carolina Louise Cardoso ${ }^{1}$ \\ ${ }^{1}$ Curso de Fonoaudiologia, Universidade Federal do Rio Grande do Sul, \\ Porto Alegre, Brazil \\ 2 Department of Surgery and Orthopedics, Federal University of Rio \\ Grande do Sul (UFRGS), Porto Alegre, Brazil
}

Erissandra Gomes ${ }^{2}$

\begin{abstract}
Address for correspondence Erissandra Gomes, PhD, Department of Surgery and Orthopedics, Federal University of Rio Grande do Sul (UFRGS), Ramiro Barcelos, 2492, Porto Alegre 90035-003, Brazil (e-mail: erifono@hotmail.com).
\end{abstract}

Int Arch Otorhinolaryngol 2016;20:275-280.

\begin{abstract}
Keywords

- lingual frenum

- therapeutics

- speech therapy

- surgical procedures

- operative
\end{abstract}

\section{Introduction}

The lingual frenum is a middle fold of mucous membrane extending from the posterior-gum surface of the tongue, covering the lingual surface of the anterior alveolar crest. ${ }^{1}$ In some cases, the lingual frenum may be changed, called ankyloglossia., ${ }^{2,3}$ This alteration is characterized by a short and thick frenum ${ }^{4-6}$ which may compromise tongue mobility. ${ }^{6-9}$ However, there are varying degrees of commitment ranging from just a short and dense fold, until anterior insertion, ${ }^{3,10}$ causing controversy over its prevalence and clinical impact.

The etiology of the altered lingual frenum is still unknown, may be associated with risk factors such as being male (2.6:1 1$)^{11}$ and a positive family history. ${ }^{6,12}$ Ankyloglossia can be considered as a relatively common disorder and studies demonstrate a prevalence ranging from 0.1 to $10.7 \%$. 613

When lingual frenum is altered and tongue mobility is affected, the subject may have problems related to feeding, such as sucking during breastfeeding, chewing and swallowing; received

May 20, 2015

accepted after revision

September 20, 2015

published online

August 12, 2015
DOI http://dx.doi.org/

10.1055/s-0035-1568135. ISSN 1809-9777.
Copyright $\odot 2016$ by Thieme Publicações License terms Ltda, Rio de Janeiro, Brazil

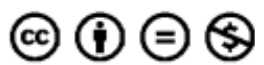


articulation of speech; dental changes; and social functions. ${ }^{1,5,8,14}$ Given the consequences related to lingual frenum alteration, often is needed to intervene and adequate tongue mobility and its functions, as well to improve the individual's quality of life.

Considering the various possibilities of intervention, including speech therapy intervention, to be performed in cases of ankyloglossia and the lack of studies on the same, it is believed a systematic review contributes to new thoughts on the theme. Thus, the objective is to conduct a systematic review of the evidence on the types of interventions used in the lingual frenum alteration and its evolution.

\section{Review of Literature}

\section{Search Strategy}

The question that guided the review was "What types of interventions are performed in the lingual frenum alteration?." From the formulation of guiding question, a bibliographic survey was conducted on the subject, interventions used in altered lingual frenum, in January 2014, in the electronic databases MEDLINE, LILACS, SciELO, Cochrane and IBECS. The search strategy applied followed recommendations of the latest version of "Cochrane Handbook for Systematic Reviews of Interventions"15. The choice of searching bases was due to its wide use by the community health sciences, and since they are source of internationally recognized references.

For the bibliographic search the following terms and combinations were used: lingual frenum $\mathrm{x}$ myofunctional therapy; lingual frenum $x$ speech therapy; lingual frenum $x$ therapeutics; ankyloglossia $\mathrm{x}$ myofunctional therapy; ankyloglossia $\mathrm{x}$ speech therapy; ankyloglossia $\mathrm{x}$ therapeutics; surgical procedures $x$ lingual frenulum; surgical procedures $\mathrm{x}$ ankyloglossia; surgery $\mathrm{x}$ lingual frenulum; surgery $\mathrm{x}$ ankyloglossia. Search terms appear in the Medical Subject Headings (MeSH) and Health Sciences Descriptors (DeCS). "Ankyloglossia" is not listed in DeCS and "lingual frenulum" does not appear in any of the mentioned, only as synonymous in Portuguese of "lingual frenum," however we decided to keep it, as it is commonly used by Speech Therapy to replace the term "lingual frenum." Searches were delimited by language (English, Portuguese and Spanish), date of publication (January/2000 to January/2014) and studies performed in humans.

\section{Selection Criteria}

The publications resulting from this search were analyzed by two researchers independently, following the following exclusion criteria: repeated articles and articles without full text available. All stages of the study were conducted independently by the researchers. When there was disagreement between the researchers, were included only the texts on which the final decision was consensual. In the sequence the articles were selected as according the execution of two-step selection. First, the articles had their abstracts analyzed, also independently and blindly considering as markers: if there were specific approach in lingual frenum, the type of study (case study/case series, clinical trial/randomized, longitudinal or transverse), and the intervention type mentioned (surgery, speech therapy, or both). It was excluded texts about craniofacial anomalies (syndromes), literature reviews, systematic reviews, opinions of experts and articles in which intervention on the frenum was not the purpose of the study. In the second stage, the selected articles have undergone a complete revision of the text, to verify if they actually met the proposed inclusion criteria. At this stage were also excluded case studies and case series, because the methodology followed the recommendations of the Oxford Center Medicine, ${ }^{16}$ using studies up to level 3 due to the scientific impact of the same.

\section{Data Analysis}

The articles selected for review were analyzed according to these aspects: study design, sample characteristics, type of intervention, intervention characteristics, main results and conclusions.

\section{Discussion}

The electronic search in database resulted in the identification of 443 publications, 259 were excluded because they were repeated and the other 86 were excluded for not having abstract and / or full text. In total 98 full-text articles had their abstracts analyzed by the researchers, from these 60 were excluded because they did not treat directly approach the lingual frenum. Thus, remaining 38 articles, 12 were excluded for being case study or case series. In the end, 26 articles were reviewed, verifying the type of study and the intervention used. All stages of the selection process and analysis of the texts are represented in - Fig. 1, based on the recommendations of the PRISMA. ${ }^{17}$

Analyzing the selected articles, it was found that there was greater scientific production on the searched topic as from the year 2002, and significant increase of publications in 2010, with an average of 3 publications per year. Most studies come from the United Kingdom ${ }^{3,13,14,18-22}$ and United States. $^{4,5,8,12,23-26}$ The rest is divided between Brazil, ${ }^{9}$ Ireland, ${ }^{27}$ Korea, ${ }^{6}$ Finland, ${ }^{7}$ Turkey, ${ }^{2}$ Australia, ${ }^{28,29}$ Canada, ${ }^{30}$ Israel $^{10}$ and Cuba. ${ }^{1}$

From the analysis of publications, one can verify that the studies had diverse objectives and characteristics. Thus, the study design, sample and type of intervention are shown in - Table 1. The studies analyzed were grouped according to population and objective, described in more detail below.

\section{Studies with Infants}

Studies show the increasing number of publications on the population of neonates and infants, due to breastfeeding difficulties associated with ankyloglossia. Some studies ${ }^{18,19,24}$ mention the promoting of breastfeeding due to its advantages and the need for intervention in cases of difficulty to do it, avoiding discontinuation. The ankyloglossia can difficult the attachment in the areola, generating inadequate pressure to milk ejection, resulting in long breastfeeding sessions and little weight gain. ${ }^{18}$ Also leads to 


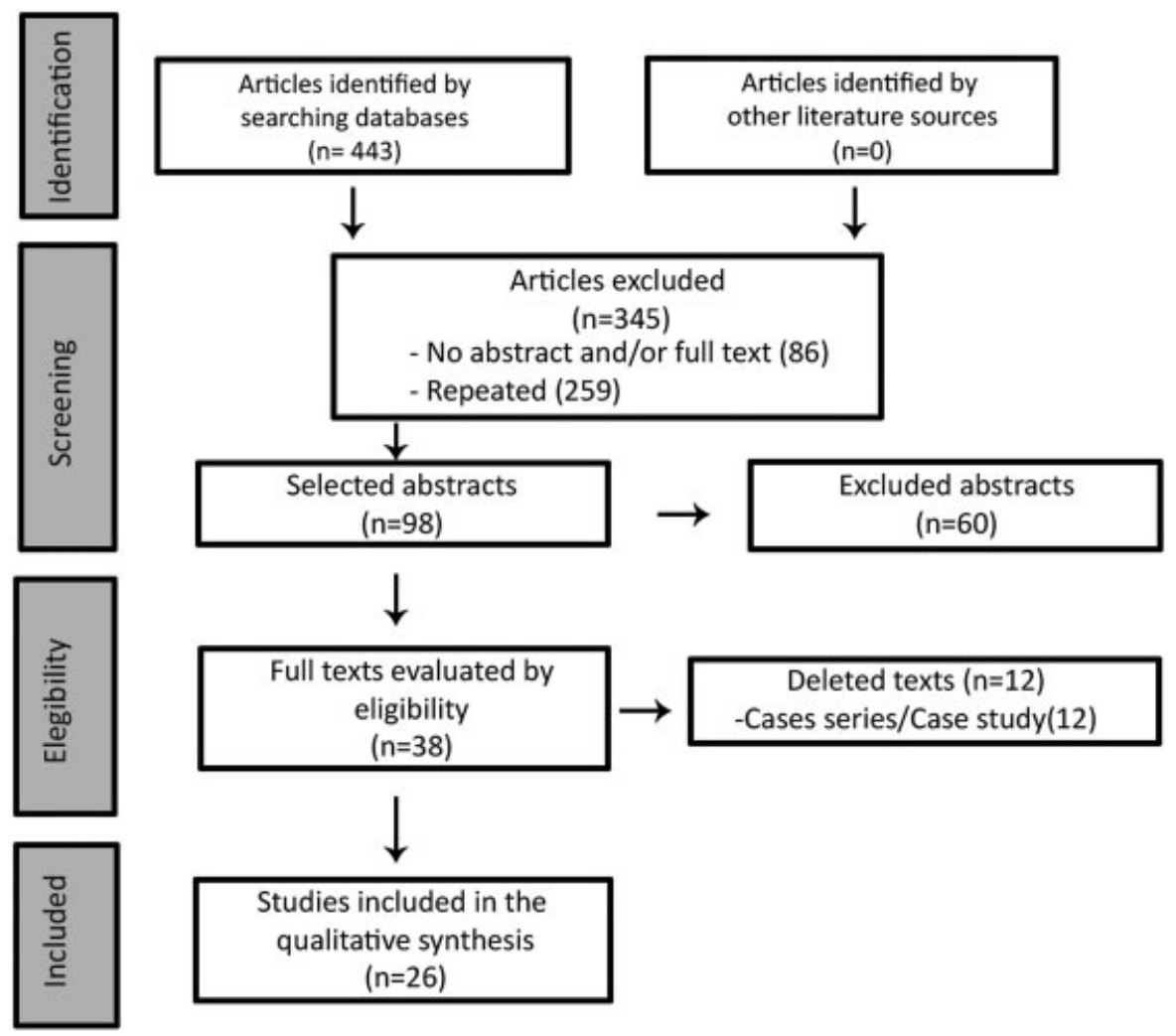

Fig. 1 Representation of the selection and analysis process of the publications.

consequences for mothers, described as: sore nipples, little milk production and mastitis. ${ }^{26}$

Many studies are intended to assess breastfeeding, but few $^{10,21,25,29,30}$ used validated protocols and / or objective measures to quantify the quality of breastfeeding and felt pain during. The rest used questionnaires answered by the mothers of children, before the procedure and during follow up, investigating through reports which difficulties exist and if they persisted after surgery. 3,8,13,18-20,22,24,26,28 There was a study ${ }^{12}$ that clinically evaluated breastfeeding before surgery, but without using protocol. In the lactation literature, surgical decision should be based on symptomatic complaints of the mother, little child's weight gain and findings of the oral examination. ${ }^{24}$ There is description about other forms of intervention, aiming to change the baby's position in the mother's breast and using maneuvers. When these conducts are not effective, there is a referral to the surgeon. $3,13,18-20,22,24-26,28-30$

One study ${ }^{19}$ mentions that some lingual frenum can be broken with the eruption of the lower teeth or objects in the mouth, not affecting the child in long-term. Thus there is no need for surgical intervention in all cases, but attention to the relationship between feeding difficulties and altered frenum enable intervention in symptomatic cases. Some studies $^{18,19,22}$ defend the instrumentalization of breastfeeding consultants, performing a simple procedure, because in this way it would decrease the delay between identification-intervention, allowing mothers persist in breastfeeding.

\section{Studies about Surgical Procedures and Techniques}

Some studies report surgery intervention using laser method. ${ }^{2,14}$ One of them ${ }^{14}$ used carbon dioxide laser in a vertical section, demonstrating that this method causes less pain and swelling postoperatively, as well as less bleeding, and improved healing compared with traditional methods. In another study ${ }^{2}$ there's comparison of the use of diode lasers and Er: YAG laser. Patients undergoing surgery with diode required local anesthesia due to discomfort, but those using Er: YAG felt greater pain $3 \mathrm{~h}$ after the surgery. Other studies ${ }^{6,23}$ mention the blade method, but using different techniques. One study ${ }^{6}$ reported cases using the technique of "z-plasty" combined with partial myotomy of the genioglossus. According to the authors, releasing the contracted portion of the muscle increases the tongue mobility and protrusion, improving speech. But the study does not mention which minimum age is indicated for this type of procedure. Another study $^{23}$ compared the horizontal-vertical techniques and "four flap z frenuloplasty." The results of the study show that the group of patients undergoing different technique had higher benefit.

\section{Studies Related to Speech Therapy}

A few selected publications mention the interdisciplinary work in relation to speech intervention. The study of children aged 1 to 12 years $^{4}$ and 3 to 9 years ${ }^{23}$ show that speech, specifically the articulation, were altered in almost every subject, and this is also an complain of parents. ${ }^{4}$ Regarding the study ${ }^{5}$ with teenagers and adults 14 to 68 years, 50\% had 
Table 1 List of articles selected for qualitative analysis

\begin{tabular}{|c|c|c|c|}
\hline Author, year & Study design & Sample & Intervention \\
\hline Puthussery et al ${ }^{14}$ & Clinical Trial, Non-Randomized & $\begin{array}{l}\mathrm{n}=21 \text { subjects } \\
\text { Sex: } \mathrm{NI} \\
\text { Age: } 3 \text { to } 30 \text { years }\end{array}$ & Surgical \\
\hline Marchesan et al $^{9}$ & Clinical Trial, Non-Randomized & $\begin{array}{l}\mathrm{n}=10 \text { subjects } \\
\text { Sex: } 80^{\star} 2 \% \\
\text { Age: } 2 \text { to } 33 \text { years }\end{array}$ & Surgical \\
\hline Wallace e Clarke ${ }^{18}$ & Clinical Trial, Non-Randomized & $\begin{array}{l}\mathrm{n}=10 \text { subjects } \\
\text { Sex: } 80^{x} 29 \\
\text { Age: } 2 \text { to } 31 \text { days }\end{array}$ & Surgical \\
\hline Hogan et al ${ }^{19}$ & Randomized Clinical Trial & $\begin{array}{l}\mathrm{n}=57 \text { subjects } \\
\text { (CG 29; EG 28) } \\
\text { Sex: NI } \\
\text { Age: } 3 \text { to } 70 \text { days }\end{array}$ & Surgical \\
\hline Glynn et $a^{27}$ & Clinical Trial, Non-Randomized & $\begin{array}{l}\mathrm{n}=48 \text { subjects } \\
\text { Sex: } 33 \sigma^{\pi} 15 \text { o } \\
\text { Age: } 3 \text { to } 192 \text { months }\end{array}$ & Surgical \\
\hline${\text { Choi et } \mathrm{al}^{6}}^{6}$ & Clinical Trial, Non-Randomized & $\begin{array}{l}\mathrm{n}=106 \text { subjects } \\
\text { Sex: } \mathrm{NI} \\
\text { Age: } 1 \text { to } 10 \text { years }\end{array}$ & Surgical \\
\hline 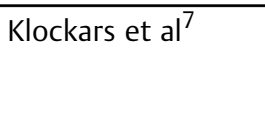 & Clinical Trial, Non-Randomized & $\begin{array}{l}\mathrm{n}=317 \text { subjects } \\
\text { Sex: } 2160^{\star} 101 \text { + } \\
\text { Age: } 0 \text { months to } 18 \text { years }\end{array}$ & Surgical \\
\hline Heller et $\mathrm{al}^{23}$ & Clinical Trial, Non-Randomized & $\begin{array}{l}\mathrm{n}=16 \text { subjects } \\
\text { Sex: } 90^{\pi} 7 \stackrel{+}{ } \\
\text { Age: } 3 \text { to } 9 \text { years }\end{array}$ & $\begin{array}{l}\text { Surgical } \\
\text { Speech therapy }\end{array}$ \\
\hline Lalakea e Messner $^{5}$ & Clinical Trial, Non-Randomized & $\begin{array}{l}\mathrm{n}=35 \text { subjects } \\
(\mathrm{CG} 20 ; \mathrm{EG} 15) \\
\text { Sex: EG } 110^{\star} 49 \\
\text { CG: NI } \\
\text { Age: EG } 14 \text { to } 68 \text { years } \\
\text { CG: } 14 \text { to } 48 \text { years }\end{array}$ & $\begin{array}{l}\text { Surgical } \\
\text { Speech therapy }\end{array}$ \\
\hline Hong et $\mathrm{al}^{8}$ & Clinical Trial, Non-Randomized & $\begin{array}{l}\mathrm{n}=341 \text { subjects } \\
\text { Sex: } 227 \sigma^{\pi} 1149 \\
\text { Age: } 1 \text { day to } 24 \text { weeks }\end{array}$ & Surgical \\
\hline Aras et $\mathrm{al}^{2}$ & Clinical Trial, Non-Randomized & $\begin{array}{l}\mathrm{n}=16 \text { subjects } \\
\text { Sex: } 80^{\star} 89 \\
\text { Age: } 18 \text { to } 27 \text { years }\end{array}$ & Surgical \\
\hline Amir et $\mathrm{al}^{28}$ & Clinical Trial, Non-Randomized & $\begin{array}{l}\mathrm{n}=46 \text { subjects } \\
\text { Sex: } 290^{\pi} 17+9 \\
\text { Age: } 3 \text { to } 98 \text { days }\end{array}$ & Surgical \\
\hline Ballard et al ${ }^{12}$ & Clinical Trial, Non-Randomized & $\begin{array}{l}\mathrm{n}=123 \text { subjects } \\
\text { Sex: } \mathrm{NI} \\
\text { Age: } \mathrm{NI}\end{array}$ & Surgical \\
\hline Mettias et $\mathrm{al}^{20}$ & Clinical Trial, Non-Randomized & $\begin{array}{l}\mathrm{n}=63 \text { subjects } \\
\text { Sex: } \mathrm{NI} \\
\text { Age: } \text { mean } 4 \text { weeks }\end{array}$ & Surgical \\
\hline Steehler et $\mathrm{al}^{24}$ & Clinical Trial, Non-Randomized & $\begin{array}{l}\mathrm{n}=367 \text { subjects } \\
\text { (CG 65; EC 302) } \\
\text { Sex: } 216 \text { o } 151 \text { \% } \\
\text { Age: mean } 18 \text { days }\end{array}$ & Surgical \\
\hline Buryk et al ${ }^{25}$ & Randomized Clinical Trial & $\begin{array}{l}\mathrm{n}=58 \text { subjects } \\
\text { (CG } 28 ; \mathrm{EG} 30) \\
\text { Sex: } 38 \text { o }^{\star} 20 \text { + } \\
\text { Age: } 1 \text { to } 35 \text { days }\end{array}$ & Surgical \\
\hline
\end{tabular}


Table 1 (Continued)

\begin{tabular}{|c|c|c|c|}
\hline Author, year & Study design & Sample & Intervention \\
\hline Miranda e Milroy ${ }^{3}$ & Clinical Trial, Non-Randomized & $\begin{array}{l}\mathrm{n}=62 \text { subjects } \\
\text { Sex: } \mathrm{Nl} \\
\text { Age: } 12 \text { to } 36 \text { days }\end{array}$ & Surgical \\
\hline Geddes et $\mathrm{al}^{29}$ & Clinical Trial, Non-Randomized & $\begin{array}{l}\mathrm{n}=24 \text { subjects } \\
\text { Sex: } \mathrm{NI} \\
\text { Age: } 1 \text { to } 131 \text { days }\end{array}$ & Surgical \\
\hline Srinivasan et $\mathrm{al}^{30}$ & Clinical Trial, Non-Randomized & $\begin{array}{l}\mathrm{n}=27 \text { subjects } \\
\text { Sex: } 18 \sigma^{7} 9+ \\
\text { Age: } 2 \text { to } 71 \text { days }\end{array}$ & Surgical \\
\hline Dollberg et al ${ }^{10}$ & Randomized Clinical Trial & $\begin{array}{l}\mathrm{n}=25 \text { subjects } \\
(\mathrm{CG} 11 ; \mathrm{EG} 14) \\
\text { Sex: } \mathrm{NI} \\
\text { Age: } 1 \text { to } 21 \text { days }\end{array}$ & Surgical \\
\hline Messner e Lalakea ${ }^{4}$ & Clinical Trial, Non-Randomized & $\begin{array}{l}\mathrm{n}=30 \text { subjects } \\
\text { Sex: } 19 \sigma^{x} 11+ \\
\text { Age: } 1 \text { to } 12 \text { years }\end{array}$ & $\begin{array}{l}\text { Surgical } \\
\text { Speech therapy }\end{array}$ \\
\hline Navarro e López ${ }^{1}$ & Clinical Trial, Non-Randomized & $\begin{array}{l}\mathrm{n}=29 \text { subjects } \\
\text { Sex: } \mathrm{NI} \\
\text { Age: } 5 \text { to } 11 \text { years }\end{array}$ & $\begin{array}{l}\text { Surgical } \\
\text { Speech therapy }\end{array}$ \\
\hline O'Callahan et al ${ }^{26}$ & Clinical Trial, Non-Randomized & $\begin{array}{l}\mathrm{n}=299 \text { subjects } \\
\text { Sex: } \mathrm{NI} \\
\text { Age: between } 2 \text { and } 323 \text { days }\end{array}$ & Surgical \\
\hline Sethi et al ${ }^{13}$ & Clinical Trial, Non-Randomized & $\begin{array}{l}\mathrm{n}=85 \text { subjects } \\
\text { Sex: } 35 \text { ơ } 17+ \\
\text { Age: } 3 \text { to } 120 \text { days }\end{array}$ & Surgical \\
\hline Berry et $\mathrm{al}^{21}$ & Randomized Clinical Trial & $\begin{array}{l}\mathrm{n}=60 \text { subjects } \\
\text { (CG } 28 ; \text { EG } 30) \\
\text { Sex: } 400^{x} 20 \text { + } \\
\text { Age: } 0 \text { to } 4 \text { months }\end{array}$ & Surgical \\
\hline Griffiths $^{22}$ & Clinical Trial, Non-Randomized & $\begin{array}{l}\mathrm{n}=215 \text { subjects } \\
\text { Sex: } \mathrm{NI} \\
\text { Age: } 0 \text { to } 3 \text { months }\end{array}$ & Surgical \\
\hline
\end{tabular}

Abbreviations: NI, Not Informed; $\sigma^{x}=$ male; + + $=$ female.

Table 2 List of articles with the highest score according to the PEDro scale $\mathrm{e}^{31}$

\begin{tabular}{|c|c|c|c|c|}
\hline & $\begin{array}{l}\text { External validity } \\
(\operatorname{Max}=1)\end{array}$ & $\begin{array}{l}\text { Internal validity } \\
(\operatorname{Max}=8)\end{array}$ & Interpretable outcomes (Max $=2$ ) & Total points $(\operatorname{Max}=11)$ \\
\hline Hogan et al ${ }^{19}$ & 1 & 4 & 2 & 7 \\
\hline Buryk et al ${ }^{25}$ & 1 & 6 & 2 & 9 \\
\hline Dollberg et al ${ }^{10}$ & 1 & 8 & 1 & 10 \\
\hline Berry et al ${ }^{21}$ & 1 & 8 & 2 & 11 \\
\hline
\end{tabular}

complaints about alteration in speech. There is also mention of the fact that some individuals with ankyloglossia develop speech normally, compensating the tongue mobility without the need of treatment, others need therapy due to the flaws in the articulation. ${ }^{4}$ Another study ${ }^{9}$ corroborates this finding, noting that some professionals refer patients before surgery to speech therapy, but this will only be effective if the alteration is not severe, because it is a mechanical disorder.
In the mentioned studies, ${ }^{4,5,9,23}$ all subjects underwent tongue exercises after surgery as protrusion, tongue position in the papilla, against the cheeks and lateralization with food. ${ }^{4,5,23}$ One study ${ }^{23}$ also added the articulation of consonants in the list of exercises, this also shows that the group which performed the 4-flap technique demonstrated greater improvement in articulation than the other. The major effects of lingual exercise are related to tongue mobility. ${ }^{23}$ There was 
a study ${ }^{5}$ which were recommended tongue mobility exercises, but there was no follow-up with a speech therapist.

To assess the subjects before and after surgery is critical to increase the scientific evidence, resulting in greater assertiveness in cases of lingual frenum alteration. ${ }^{9}$

\section{Scientific Evidence}

To check the scientific evidence of the studies, we used the PEDro scale. $^{31,32}$ The purpose of the scale is to help researchers identify if the clinical outcomes of therapies applied meet the criteria exposed. 11 checklist items investigate as to internal validity, external validity and results that can be interpreted statistically. All 26 studies were analyzed by this scale, however only 4 scored more, as described in - Table $\mathbf{2}$. Studies have many similarities as: study design, population of neonates and infants, use of surgical intervention (frenotomy), main results of less pain felt by mothers and improve in breastfeeding.

\section{Final Comments}

From the selected studies, all resort to surgical option to treat cases of ankyloglossia. In the population of neonates and infants, the most used is the frenotomy by using cold instrument (scissors or scalpel), without the use of anesthetic. In the population of children and adults, techniques and instruments differ among authors. All results show that surgery is the most effective for improvement of symptoms due to ankyloglossia condition. However, the speech does not always fit the expected pattern, which justifies the work together with professional speech therapist, for better results. The theme is scientific important, face to ankyloglossia consequences in aspects of oral functions. It's needed an interdisciplinary team with doctors, dentists and speech therapists trained for assessment, diagnosis and intervention when necessary.

\section{References}

1 Navarro NP, López LM. Anquiloglosia en niños de 5 a 11 años de edad. Diagnóstico y tratamiento. Rev Cubana Estomatol 2002;39(3):1-8

2 Aras MH, Göregen M, Güngörmüş M, Akgül HM. Comparison of diode laser and Er:YAG lasers in the treatment of ankyloglossia. Photomed Laser Surg 2010;28(2):173-177

3 Miranda BH, Milroy CJ. A quick snip - A study of the impact of outpatient tongue tie release on neonatal growth and breastfeeding. J Plast Reconstr Aesthet Surg 2010;63(9):e683-e685

4 Messner AH, Lalakea ML. The effect of ankyloglossia on speech in children. Otolaryngol Head Neck Surg 2002;127(6):539-545

5 Lalakea ML, Messner AH. Ankyloglossia: the adolescent and adult perspective. Otolaryngol Head Neck Surg 2003;128(5):746-752

6 Choi YS, Lim JS, Han KT, Lee WS, Kim MC. Ankyloglossia correction: Z-plasty combined with genioglossus myotomy. J Craniofac Surg 2011;22(6):2238-2240

7 Klockars T, Pitkäranta A. Pediatric tongue-tie division: indications, techniques and patient satisfaction. Int J Pediatr Otorhinolaryngol 2009;73(10):1399-1401

8 Hong P, Lago D, Seargeant J, Pellman L, Magit AE, Pransky SM. Defining ankyloglossia: a case series of anterior and posterior tongue ties. Int J Pediatr Otorhinolaryngol 2010;74(9):1003-1006

9 Marchesan IQ Martinelli RLC, Gusmão RJ. Frênulo lingual: modificações após frenectomia. J Soc Bras Fonoaudiol. 2012;24(4):409-412
10 Dollberg S, Botzer E, Grunis E, Mimouni FB. Immediate nipple pain relief after frenotomy in breast-fed infants with ankyloglossia: a randomized, prospective study.J Pediatr Surg 2006;41(9):1598-1600

11 Fitz-Desorgher R. All tied up. Tongue tie and its implications for breastfeeding. Pract Midwife 2003;6(1):20-22

12 Ballard JL, Auer CE, Khoury JC. Ankyloglossia: assessment, incidence, and effect of frenuloplasty on the breastfeeding dyad. Pediatrics 2002;110(5):e63

13 Sethi N, Smith D, Kortequee S, Ward VMM, Clarke S. Benefits of frenulotomy in infants with ankyloglossia. Int J Pediatr Otorhinolaryngol 2013;77(5):762-765

14 Puthussery FJ, Shekar K, Gulati A, Downie IP. Use of carbon dioxide laser in lingual frenectomy. Br J Oral Maxillofac Surg 2011;49(7): 580-581

15 Higgins JPT, Green S, Eds. Cochrane Handbook for Systematic Reviews of Interventions - Version 5.1.0 [Internet]. The Cochrane Collaboration, 2011. Available at: http://www.cochrane-handbook.org. Accessed in Aug 31, 2014.

16 OCEBM Levels of Evidence Working Group* [Internet]. "The Oxford 2011 Levels of Evidence". Available at: http://www.cebm. net/mod_product/design/files/CEBM-Levels-of-Evidence-2.1.pdf. Accessed in Aug 31, 2014.

17 Moher D, Liberati A, Tetzlaff J, Altman DG; PRISMA Group. Preferred reporting items for systematic reviews and meta-analyses: the PRISMA statement. PLoS Med 2009;6(7):e1000097

18 Wallace $\mathrm{H}$, Clarke S. Tongue tie division in infants with breast feeding difficulties. Int J Pediatr Otorhinolaryngol 2006;70(7): 1257-1261

19 Hogan M, Westcott C, Griffiths M. Randomized, controlled trial of division of tongue-tie in infants with feeding problems. J Paediatr Child Health 2005;41(5-6):246-250

20 Mettias B, O'Brien R, Abo Khatwa MM, Nasrallah L, Doddi M. Division of tongue tie as an outpatient procedure. Technique, efficacy and safety. Int J Pediatr Otorhinolaryngol 2013;77(4):550-552

21 Berry J, Griffiths M, Westcott C. A double-blind, randomized, controlled trial of tongue-tie division and its immediate effect on breastfeeding. Breastfeed Med 2012;7(3):189-193

22 Griffiths DM. Do tongue ties affect breastfeeding? J Hum Lact 2004;20(4):409-414

23 Heller J, Gabbay J, O'Hara C, Heller M, Bradley JP. Improved ankyloglossia correction with four-flap Z-frenuloplasty. Ann Plast Surg 2005;54(6):623-628

24 Steehler MW, Steehler MK, Harley EH. A retrospective review of frenotomy in neonates and infants with feeding difficulties. Int J Pediatr Otorhinolaryngol 2012;76(9):1236-1240

25 Buryk M, Bloom D, Shope T. Efficacy of neonatal release of ankyloglossia: a randomized trial. Pediatrics 2011;128(2):280-288

26 O'Callahan C, Macary S, Clemente S. The effects of office-based frenotomy for anterior and posterior ankyloglossia on breastfeeding. Int J Pediatr Otorhinolaryngol 2013;77(5):827-832

27 Glynn RW, Colreavy M, Rowley H, Gendy S. Division of tongue tie: review of practice through a tertiary paediatric otorhinolaryngology service. Int J Pediatr Otorhinolaryngol 2012;76(10):1434-1436

28 Amir LH, James JP, Donath SM. Reliability of the hazelbaker assessment tool for lingual frenulum function. Int Breastfeed $\mathrm{J}$ 2006;1(1):3

29 Geddes DT, Langton DB, Gollow I, Jacobs LA, Hartmann PE, Simmer K. Frenulotomy for breastfeeding infants with ankyloglossia: effect on milk removal and sucking mechanism as imaged by ultrasound. Pediatrics 2008;122(1):e188-e194

30 Srinivasan A, Dobrich C, Mitnick H, Feldman P. Ankyloglossia in breastfeeding infants: the effect of frenotomy on maternal nipple pain and latch. Breastfeed Med 2006;1(4):216-224

31 Centro de Fisioterapia Baseada em Evidências (CEBP) [Internet]. Available at: http://www.pedro.org.au/portuguese/downloads/ pedro-scale/. Accessed in Aug 31, 2014.

32 Shiwa SR, Costa LOP, Moser ADL, Aguiar IC, Oliveira LVF. PEDro: A base de dados da fisioterapia. Fisioter Mov 2011;24(3):523-533 